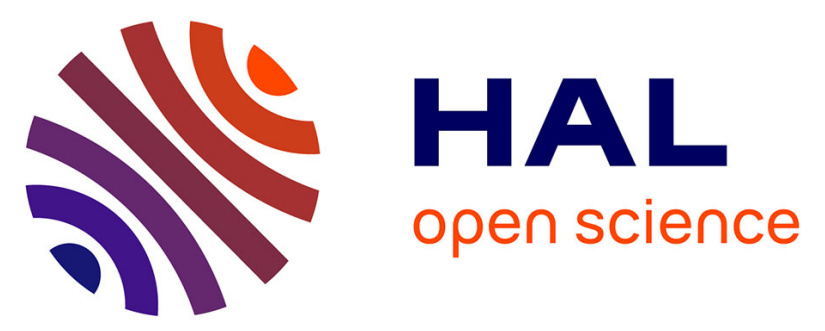

\title{
Efficiency of Industrially Relevant Atropisomeric Diphosphines in Copper-Catalyzed 1,4-Asymmetric Conjugate Addition of Dialkylzincs to Cyclic or Acyclic Enones or Dienones
}

Marie S. T. Morin, Thomas Vives, Olivier Baslé, Christophe Crévisy, Virginie Ratovelomanana-Vidal, Marc Mauduit

\section{To cite this version:}

Marie S. T. Morin, Thomas Vives, Olivier Baslé, Christophe Crévisy, Virginie RatovelomananaVidal, et al.. Efficiency of Industrially Relevant Atropisomeric Diphosphines in Copper-Catalyzed 1,4-Asymmetric Conjugate Addition of Dialkylzincs to Cyclic or Acyclic Enones or Dienones. Synthesis: Journal of Synthetic Organic Chemistry, 2015, 47 (17), pp.2570-2577. 10.1055/s-0034-1378813 . hal-01188236

\section{HAL Id: hal-01188236 \\ https://hal-univ-rennes1.archives-ouvertes.fr/hal-01188236}

Submitted on 19 Oct 2015

HAL is a multi-disciplinary open access archive for the deposit and dissemination of scientific research documents, whether they are published or not. The documents may come from teaching and research institutions in France or abroad, or from public or private research centers.
L'archive ouverte pluridisciplinaire HAL, est destinée au dépôt et à la diffusion de documents scientifiques de niveau recherche, publiés ou non, émanant des établissements d'enseignement et de recherche français ou étrangers, des laboratoires publics ou privés. 


\section{Efficiency of Industrially Relevant Atropisomeric Diphosphines in Copper- Catalyzed 1,4-Asymmetric Conjugate Addition of Dialkylzincs to (a)Cyclic (di)Enones}

Marie S. T. Morin ${ }^{\mathrm{a}}$, Thomas Vives ${ }^{\mathrm{a}}$, Olivier Basléa ${ }^{\mathrm{a}}$ Christophe Crévisy*a, Virginie Ratovelomanana-Vidal ${ }^{\mathrm{b} *}$, Marc $^{*}$ Mauduit $^{\mathrm{a} *}$

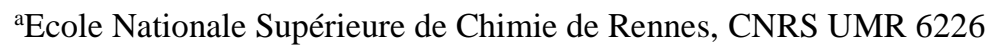

11 Allée de Beaulieu, CS 50837, 35708, Rennes Cedex 7, France

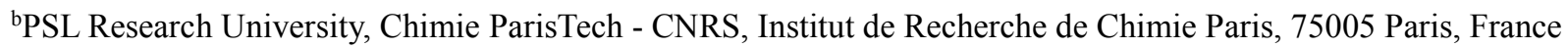

Fax: +33223238112

E-mail:marc.mauduit@ensc-rennes.fr

Received: The date will be inserted once the manuscript is accepted.

\footnotetext{
Abstract: Industrially relevant atropisomeric diphosphines such as BINAP, SYNPHOS and DIFLUORPHOS have demonstrated their efficiency in the copper-catalyzed asymmetric conjugate addition of various dialkylzincs to $\alpha$-aryl enones, $\alpha$-aryl dienones and cyclic dienones. Excellent 1,4- or 1,6-regioselectivities and enantioselectivities (up to 97\% ee) were reached, even with challenging stericallyhindered Michael acceptors.
}

Key words: $\alpha$-Aryl enones; Dienones; Conjugate addition; Copper; Dialkylzinc reagents; BINAP; SYNPHOS, DIFLUORPHOS

In the field of modern asymmetric synthesis, the metal-catalyzed Asymmetric Conjugate Addition (ACA) represents one of the most powerful methods to build valuable optically active compounds for the pharmaceutical and agrochemical industries. ${ }^{1}$ In this regard, intensive research in the ligand design has been performed over the last two decades, notably for copper-catalyzed ACA. ${ }^{2}$ Among the plethora of phosphorus-based ligands described in this area, atropoisomeric chiral phosphoramidites and phosphines have been deeply studied affording the expected 1,4-adducts in good yields and remarkable enantioselectivities. ${ }^{2}$ Curiously, although atropoisomeric diphosphines were successfully used in the $\mathrm{Cu}$-catalyzed addition of trialkylaluminium or Grignard reagents to various cyclic and/or acyclic $\alpha, \beta$ unsaturated carbonyls (ketones, ${ }^{3}$ esters ${ }^{4}$, thioesters ${ }^{5}$ and $\alpha$-ketoesters ${ }^{6}$ ) (Scheme $1, \mathrm{~A}$ ), to the best of our knowledge, no report concerned the addition of less reactive hard nucleophiles such as dialkylzinc reagents. Very recently, we serendipitously discovered the efficiency of $(R)$-BINAP (L-1) as a ligand in the Cu-catalyzed 1,4-ACA of diethylzinc to linear enones (ees ranging from 82 to $99 \%$ ). ${ }^{7}$ Remarkably, the $\mathrm{Cu} / \mathrm{BINAP}$ catalytic system appeared particularly efficient with $\delta$-branched $\alpha, \beta$-unsaturated aryl ketones. The value of these catalytic processes allowed the efficient development of a highly regio- and enantioselective sequential 1,6/1,4 addition involving acyclic dienones (de $>97 \%$ ) (Scheme 1, B). As a result of these pioneering results, we were prompted to extend our study and to evaluate a series of industrially relevant atropoisomeric diphosphine ligands such as BINAP (L-1), $(S)-S Y N P H O S(\text { L-2 })^{8}$ and $(R)$ DIFLUORPHOS $(\mathbf{L - 3})^{9}$ in the selective conjugate addition of dialkylzincs to various $\alpha$-aryl enones, $\alpha$-aryl dienones and cyclic dienones (Scheme 1, C). 


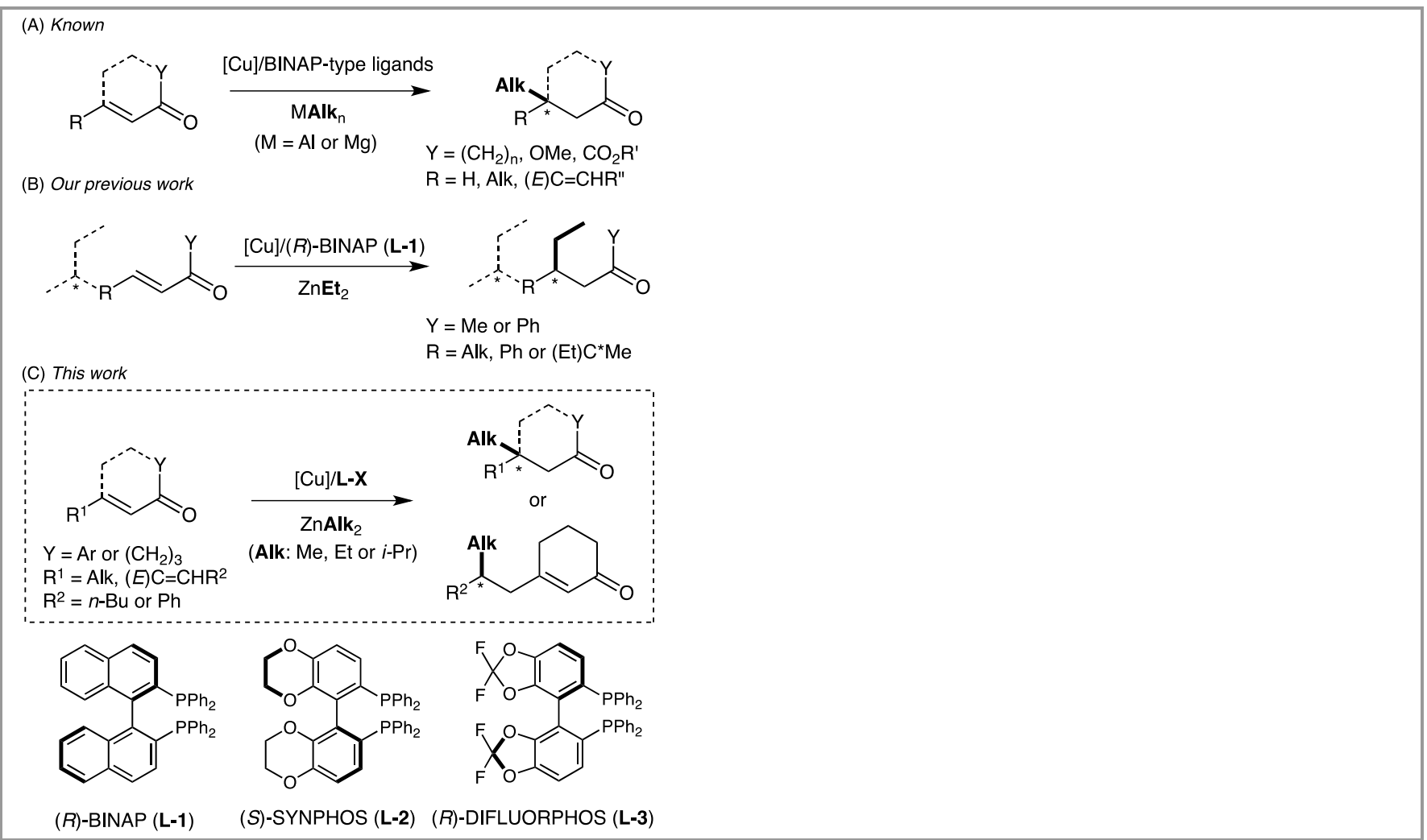

Scheme 1 Copper-catalyzed conjugate additions involving atropisomeric ligands

The screening of atropisomeric ligands L1-3 was started with the conjugate addition of diethylzinc to the sterically hindered cyclohexyl-substituted $\alpha$-phenyl enone 1a (Table 1), a challenging Michael acceptor that has been scarcely studied to date. ${ }^{10}$ Under optimized reaction conditions (copper-thiophene-2-carboxylate $(\mathrm{CuTc}) / \mathbf{L}-\mathbf{X} 5 \mathrm{~mol} \%$, THF, room temperature, Table 1, entry 1), $(R)$-BINAP (L-1) afforded the expected 1,4-adduct 2a in $92 \%$ isolated yield and high enantioselectivity ( $97 \%$ ee). At lower catalyst loading, the enantioselectivity of the addition decreased to $88 \%$ ee (Table 1, entry 2). 


$\overbrace{\text { 1a-f }}^{\text {ZnAlk }} \underset{\text { equiv }}{\stackrel{\text { CuTc }(5 \mathrm{~mol} \%)}{\mathrm{L-X}(5 \mathrm{~mol} \%)}}$

\begin{tabular}{|c|c|c|c|c|c|c|c|c|}
\hline $\begin{array}{c}\text { Entr } \\
\mathrm{y}\end{array}$ & 1 & $\mathrm{Ar}$ & $\mathrm{R}$ & Alk & $\begin{array}{l}\text { L- } \\
\text { X } \\
\end{array}$ & Product & $\begin{array}{l}\text { Yield } \\
(\%)^{b}\end{array}$ & $\begin{array}{c}e e \\
(\%)^{c}\end{array}$ \\
\hline 1 & \multirow{4}{*}{$1 \mathrm{a}$} & \multirow{4}{*}{$\mathrm{Ph}$} & \multirow{4}{*}{ Cy } & \multirow{4}{*}{ Et } & L-1 & & 92 & $97(S)$ \\
\hline $2^{\mathrm{d}}$ & & & & & L-1 & & 91 & $88(S)$ \\
\hline 3 & & & & & L-2 & & 92 & $90(R)$ \\
\hline 4 & & & & & L-3 & & 98 & $93(S)$ \\
\hline $5^{\mathrm{e}}$ & $1 b$ & $\mathrm{Ph}$ & $\mathrm{Me}$ & Et & L-1 & & 74 & 99 \\
\hline 6 & $1 c$ & 2-Nph & Cy & Et & L-1 & & 89 & 94 \\
\hline 7 & $1 \mathrm{a}$ & $\mathrm{Ph}$ & Cy & $i-\operatorname{Pr}$ & L-1 & & 54 & 12 \\
\hline 8 & & & & & L-1 & & 96 & 91 \\
\hline 9 & 1d & $\mathrm{Ph}$ & $\begin{array}{l}\mathrm{CH}_{2} \\
t-\mathrm{Bu}_{\mathrm{u}}\end{array}$ & $\mathrm{Et}$ & L-2 & & 96 & -89 \\
\hline 10 & & & & & L-3 & & 98 & 83 \\
\hline $11^{\mathrm{e}}$ & 1e & $\mathrm{Ph}$ & $i$-Bu & Et & L-1 & & 85 & 94 \\
\hline 12 & $1 d$ & $\mathrm{Ph}$ & $\begin{array}{l}\mathrm{CH}_{2} \\
t-\mathrm{Bu}\end{array}$ & $\mathrm{Me}$ & L-1 & & 44 & 93 \\
\hline $13^{\mathrm{f}}$ & 1e & $\mathrm{Ph}$ & $i$-Bu & $\mathrm{Me}$ & L-1 & & 30 & 91 \\
\hline 14 & 1f & $\mathrm{Ph}$ & $t$-Bu & Et & L-1 & & $22^{\mathrm{g}}$ & 0 \\
\hline
\end{tabular}

${ }^{a}$ Reaction conditions: 1a-f $(0.5 \mathrm{mmol}), \mathrm{Et} 2 \mathrm{Zn}(1.5 \mathrm{mmol})$, CuTc $(0.025 \mathrm{mmol}), \mathbf{L}-\mathbf{X}(0.025 \mathrm{mmol})$, THF (0.5 mL), rt, 14 to $36 \mathrm{~h}$.

${ }^{\mathrm{b}}$ Isolated yield. ${ }^{\mathrm{c}}$ Determined by GC on 2 (see ESI).

${ }^{\mathrm{d}}$ Reaction performed with $2 \mathrm{~mol} \%$ of $\mathrm{CuTc} / \mathrm{L}-1 .{ }^{\text {e }} \mathrm{A}$ 1:1.5 MeTHF/Cyclohexane ratio was used at $-40^{\circ} \mathrm{C}$, see ref. 7 .

${ }^{\mathrm{f}} \mathrm{A} 1: 1.5 \mathrm{MeTHF} / \mathrm{Cyclohexane}$ ratio was used at $0^{\circ} \mathrm{C}$, see ref. 7 .

${ }^{\mathrm{g}}{ }^{1} \mathrm{H}$ NMR yield with internal standard (see ESI).

In the case of (S)-SYNPHOS (L-2) and (R)-DIFLUORPHOS (L-3), similar excellent yields were reached (up to 98\%) but with slightly lower enantioselectivity (90\% and $93 \%$ ee, respectively, entries $2-3)$. One should note that the results obtained for $2 \mathbf{a}$ are equivalent to the best results reported in the literature both in term of isolated yield and enantioselectivity ${ }^{11}$ Moreover, in comparison with the less hindered substrate $\mathbf{1 b}$ bearing a methyl group,${ }^{7}$ the erosion of enantioselectivity remained exceptionally quite low (entry $4,99 \%$ ee $v s$ entry $1,97 \%$ ee). On the other hand, the replacement of the phenyl ketone function by the more bulky 2-naphthyl ketone fragment only led to a slight decrease of the efficiency to form the corresponding adduct $\mathbf{2 c}$ with excellent $89 \%$ isolated yield and $94 \%$ enantiomeric excess (entry 6). In view of these studies, we decided to extend the scope by attempting the addition of a bulkier alkyl nucleophile such as $i-\operatorname{Pr}_{2} \mathrm{Zn}$ (entry 7). The corresponding 1,4-adduct $\mathbf{2 d}$ was isolated for the first time with a moderate isolated yield of $54 \%$, despite a prolonged reaction time $(36 \mathrm{~h})$. Unfortunately, the enantioselectivity of the addition was quite low $(12 \%$ ee). The latter result illustrated a limit of the BINAP ligand (L1) toward sterically-demanding ACA involving organozinc reagents as nucleophiles. We pursued our ligand screening in the addition of $\mathrm{Et}_{2} \mathrm{Zn}$ to the newly synthesized $\alpha$-phenyl enone 1d bearing a tert-butylCH${ }_{2}$ side chain (entries 8-10). Again, the BINAP ligand (L-1) appeared to be the most efficient one, affording the 1,4-adduct $2 \mathrm{e}$ in excellent $96 \%$ isolated yield and $91 \%$ ee, while $(S)$-SYNPHOS (L-2) and (R)-DIFLUORPHOS (L-3) reached 89 and 83\% ee, respectively. The steric hindrance from 
the $\mathrm{CH}_{2}$ t-Bu group had slightly altered the enantioselectivity of the addition in comparison with adduct $\mathbf{2} \mathbf{f}$ bearing an isobutyl side chain ( 91 vs 94\% ee, entries 8 and 11). Noteworthy, the addition of the less reactive dimethylzinc to enone 1d was less productive, affording the corresponding 1,4-adduct $\mathbf{2 g}$ in $44 \%$ isolated yield, while the enantioselectivity remained excellent reaching $93 \%$ ee, in the same range as the previously reported adduct $\mathbf{2 h}$ (entries 12-13). Unfortunately, the addition of diethylzinc to the more sterically-demanding enone 1f bearing a $t$-Bu moiety was unsuccessful leading only to racemic product $2 \mathbf{i}$ in $22 \%$ yield (entry 14 ). ${ }^{11}$ In comparison with previously reported copper-catalytic systems involving BINAP-type ligands for the 1,4-ACA of alkyl Grignard ${ }^{3,4}$ or trialkylaluminum ${ }^{6}$ reagents to electron deficient unsaturated systems, our methodology gave similar efficiency both in term of isolated yields and enantioselectivities.

The capacity to control both the regio- and the enantioselectivity in metal-catalyzed conjugate addition involving electrophilic extended unsaturated systems remains a challenge for organic chemists and the development of new catalytic systems is highly desirable. ${ }^{12}$ Therefore, having proved the efficiency of BINAP (L-1) toward simple aliphatic $\alpha$-aryl enones, we then decided to extend this method to the more challenging acyclic and cyclic dienic Michael acceptors to produce either 1,6- or 1,4-adducts. ${ }^{13}$ First, we tried the addition of diethylzinc to $\alpha$-phenyl dienone $\mathbf{1 g}$ (Table 2). We were pleased to observe that BINAP (L-1) promoted an excellent regioselectivity in favor of the 1,4adduct $2 \mathbf{j}$ (96/4 ratio) with $82 \%$ isolated yield after $3 \mathrm{~h}$ at room temperature and up to $92 \%$ ee (entry 1 ). This $1,4-$ selectivity was also recently observed with $\mathbf{L}-\mathbf{1}$ for the addition of $\mathrm{AlMe}_{3}$ on an $\alpha$-ketoester analogue, as reported by Alexakis and Gremaud (98\% ee). ${ }^{6}$ When $(S)$-SYNPHOS (L-2) and $(R)$-DIFLUORPHOS (L-3) were used, the additions were completed after 5 to $6 \mathrm{~h}$ to furnish $\mathbf{2 j}$ with a similarly high level of regioselectivity $(97 / 3$ and $95 / 5$ respectively, entries $2-3$ ) but with lower ees ( $54 \%$ and $80 \%$ respectively). It is important to notice that enantioenriched 1,4 -adducts such as $\mathbf{2} \mathbf{j}$ could be easily transformed into valuable synthetic intermediates through the post-oxidation of the phenylketone as reported by Coates and Sowerby during the synthesis of Zizaene ${ }^{14}$ or the styrenyl side chain as described by Zhang and co-workers. ${ }^{13 f}$

Table 2 Screening of atropisomeric ligands in 1,4 Cu-ACA of Et $2 \mathrm{Zn}$ to $\alpha$-aryl dienone $\mathbf{1 g}^{\mathrm{a}}$

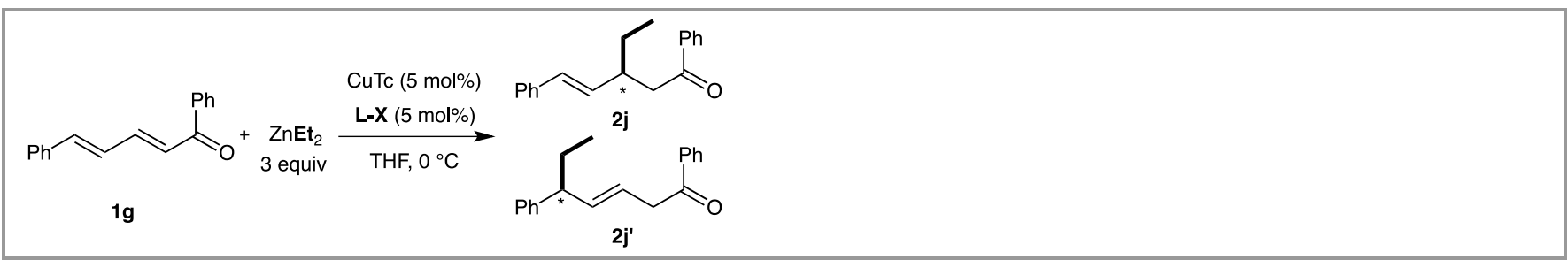

\begin{tabular}{|c|c|c|c|c|c|}
\hline Entry & L-X & Time (h) & $\begin{array}{c}\text { Ratio } \\
\mathbf{2 j} / \mathbf{2} \mathbf{j}^{\mathrm{b}}\end{array}$ & ${\text { Yield }(\%)^{\mathrm{c}}}$ & $\boldsymbol{e e}(\%)^{\mathrm{d}}$ \\
\hline 1 & $\mathbf{L - 1}$ & $\mathbf{3}$ & $\mathbf{9 6 / 4}$ & $\mathbf{8 2}$ & $\mathbf{9 2}$ \\
\hline 2 & $\mathbf{L - 2}$ & 5 & $97 / 3$ & 70 & -54 \\
\hline 3 & $\mathbf{L - 3}$ & 6 & $95 / 5$ & 66 & 80 \\
\hline
\end{tabular}

${ }^{\text {a }}$ Reaction conditions: $\mathbf{1 g}(0.5 \mathrm{mmol}), \mathrm{Et}_{2} \mathrm{Zn}(1.5 \mathrm{mmol})$, CuTc $(0.025 \mathrm{mmol}), \mathbf{L}-\mathbf{X}(0.025 \mathrm{mmol}), \mathrm{THF}(0.5 \mathrm{~mL}), 0{ }^{\circ} \mathrm{C}, 3$ to $6 \mathrm{~h}$.

${ }^{b}$ Determined by ${ }^{1} \mathrm{H}$ NMR spectroscopy. ${ }^{\mathrm{c}}$ Isolated yield of $\mathbf{2} \mathbf{j} / \mathbf{2} \mathbf{j}$ '.

${ }^{\mathrm{d}}$ Determined by GC on 2 (see ESI).

We finally focused our attention on the enantioselective addition of diethylzinc to the cyclic dienone $\mathbf{1 h}$ (Table 3 ). Although the relative steric hindrances at the $\beta$ and $\delta$ positions should favour the 1,6-addition, it was previously observed that the regioisomeric outcome of such a reaction is also under strong dependence of the nature of both the nucleophile and the chiral ligand. ${ }^{15} \mathrm{Using}$ a $\mathrm{Cu}$ /diphosphine $\mathbf{L 1 - 3}$ catalytic system, a complete regioselectivity in favour of the 1,6-adduct $\mathbf{2 k}$ was observed (after reconjugation in the presence of DBU). With $(R)$-BINAP $(\mathbf{L}-\mathbf{1})$, complete conversion occurred after $5 \mathrm{~h}$ at room temperature, furnishing $\mathbf{2 k}$ in $60 \%$ isolated yield and $82 \%$ ee (entry 1 ). At lower temperature, the enantioselectivity was not improved and the yield decreased significantly to $26 \%$ despite $21 \mathrm{~h}$ of reaction (entry 2). A similar level of enantio-induction was reached with $(S)$-SYNPHOS (L-2), however the addition was less productive after $14 \mathrm{~h}$ of reaction at room temperature (54\% of yield, entry 3$)$. (R)-DIFLUORPHOS (L-3) appeared also less efficient under the same reaction conditions, yielding the 1,6-adduct in only $14 \%$ yield with $74 \%$ of enantioselectivity (entry 4).

In conclusion, we have demonstrated the efficiency of atropoisomeric diphosphines ligands in the enantioselective conjugate addition of dialkylzinc reagents onto $\alpha$-aryl enones, $\alpha$-aryl dienones as well as cyclic dienones by using CuTc as a catalyst. The industrially relevant $(R)$-BINAP proved superior to both $(S)$-SYNPHOS and $(R)$-DIFLUORPHOS as a ligand for this transformation both in terms of productivity and enantioselectivity, providing valuable 1,4- and 1,6- 
adducts in relatively good isolated yields and up to $97 \%$ ee. Unfortunately, highly sterically demanding enones or bulky organozinc reagents remain problematic leading only to moderate yields and low enantioselection.

Table 3 Screening of atropisomeric ligands in 1,6 Cu-ACA of $\mathrm{Et}_{2} \mathrm{Zn}$ to cyclic dienone $\mathbf{1 h}^{\mathrm{a}}$

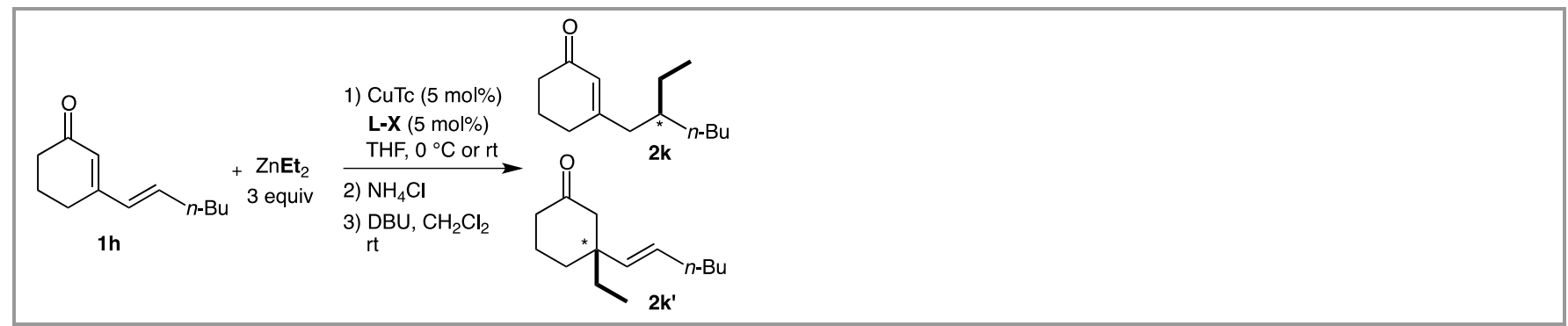

\begin{tabular}{|c|c|c|c|c|c|c|}
\hline Entry & L-X & $\mathrm{T}\left({ }^{\circ} \mathrm{C}\right)$ & Time (h) & $\begin{array}{c}\text { Ratio } \\
\mathbf{2 k} / \mathbf{2} \mathbf{k}^{\mathrm{b}}\end{array}$ & $\begin{array}{c}\text { Yield } \\
(\%)^{\mathrm{c}}\end{array}$ & ee $(\%)^{\mathrm{d}}$ \\
\hline 1 & $\mathbf{L - 1}$ & $\mathbf{r t}$ & $\mathbf{5}$ & $>98 / 2$ & $\mathbf{6 0}$ & $\mathbf{8 2}$ \\
\hline 2 & $\mathbf{L}-1$ & 0 & 21 & $>98 / 2$ & 26 & 82 \\
\hline 3 & $\mathbf{L - 2}$ & $\mathrm{rt}$ & 14 & $>98 / 2$ & 54 & -82 \\
\hline 4 & $\mathbf{L - 3}$ & $\mathrm{rt}$ & 14 & $>98 / 2$ & $14^{\mathrm{e}}$ & 74 \\
\hline
\end{tabular}

${ }^{a}$ Reaction conditions: $\mathbf{1 h}(0.5 \mathrm{mmol}), \mathrm{Et}_{2} \mathrm{Zn}(1.5 \mathrm{mmol})$, CuTc $(0.025 \mathrm{mmol}), \mathbf{L}-\mathbf{X}(0.025 \mathrm{mmol})$, THF $(0.5 \mathrm{~mL}), \mathrm{rt}, 5$ to $21 \mathrm{~h}$.

${ }^{\mathrm{b}}$ Determined by ${ }^{1} \mathrm{H}$ NMR spectroscopy. ${ }^{\mathrm{c}}$ Isolated yield of $\mathbf{2 k}$.

${ }^{\mathrm{d}}$ Determined by GC on 2 (see ESI). ${ }^{\mathrm{e}} \mathrm{H}$ NMR yield with internal standard (see ESI).

Further developments for such challenging reactions are currently under investigation in our group and will be applied in the enantioselective synthesis of bio-relevant targets. In that context, BINAP is a commercially available and rather inexpensive chiral ligand that has already demonstrated its potential for industrial applications. ${ }^{16}$ Consequently, the fact that a $\mathrm{Cu} / \mathrm{BINAP}$ system catalyses efficiently and selectively various ACA of dialkylzincs to both enones and dienones is of a great interest in organic synthesis.

All reactions were performed under an argon atmosphere using oven-dried glassware. $\mathrm{Et}_{2} \mathrm{Zn}$ and $i-\mathrm{Pr}_{2} \mathrm{Zn}$ were purchased from Aldrich and used without further purification. Me $2 \mathrm{Zn}$ was purchased from Acros and used without further purification. Substrates $\mathbf{1 a}^{17}, \mathbf{1 f}^{18}, \mathbf{1 g}^{19}$ and $\mathbf{1 h}^{13 \mathrm{~b}}$ were synthesized as reported in the literature. THF was distilled from $\mathrm{Na}$ /benzophenone under argon and dichloromethane was distilled from calcium hydride under nitrogen. All other chemical reagents and solvents were obtained from commercial sources and used without further purification. ${ }^{1} \mathrm{H}(400 \mathrm{MHz}),{ }^{13} \mathrm{C}(100 \mathrm{MHz})$, NMR spectra were recorded on a Bruker ARX400 spectrometer with complete proton decoupling for nuclei other than ${ }^{1} \mathrm{H}$. Chemical shifts are reported in ppm with the solvent resonance as the internal standard $\left(\mathrm{CDCl}_{3}\right.$, ${ }^{1} \mathrm{H}: \delta 7.26 \mathrm{ppm},{ }^{13} \mathrm{C}: \delta 77.16 \mathrm{ppm}$ ). Data are reported as follows: chemical shift $(\delta$ in ppm, multiplicity $(\mathrm{s}=$ singlet, $\mathrm{d}=\mathrm{doublet}, \mathrm{t}=$ triplet, $\mathrm{q}=$ quartet, quint $=$ quintuplet, $\mathrm{sept}=$ septuplet, $\mathrm{m}=$ multiplet $)$, coupling constants $(\mathrm{Hz})$ and integration. Optical rotations were recorded using a polarimeter Perkin-Elmer 341. High resolution mass spectrometry analyses were performed at the Centre Régional de Mesures Physiques de l'Ouest (CRMPO), Université de Rennes 1. Enantiomeric excesses were measured using gas chromatography (capillary column - Chiraldex Beta-dex, $30 \mathrm{~m}$ x $0.25 \mathrm{~mm}$ id, $0.25 \mu \mathrm{m}$ or G-TA, $30 \mathrm{~m}$ x $0.25 \mathrm{~mm}$ id, $0.12 \mu \mathrm{m}$ ) or HPLC (Chiralcel OJ-H or IA columns).

\section{(E)-3-cyclohexyl-1-(naphthalene-2-yl)prop-2-en-1-one (1c)}

According the literature procedure ${ }^{17}$ and starting from cyclohexanecarboxaldehyde $(5 \mathrm{mmol})$, the desired enone $1 \mathrm{c}$ was obtained in $61 \%$ yield $(806 \mathrm{mg})$.

${ }^{1} \mathbf{H}$ NMR $\left(400 \mathrm{MHz} ; \mathrm{CDCl}_{3}\right): \delta 8.44(\mathrm{~s}, 1 \mathrm{H}), 8.02(\mathrm{dd}, J=8.6 \mathrm{~Hz}, 1.7 \mathrm{~Hz}, 1 \mathrm{H}), 7.97(\mathrm{~d}, J=8.0 \mathrm{~Hz}, 1 \mathrm{H}), 7.90(\mathrm{t}, J=9.0 \mathrm{~Hz}, 2 \mathrm{H}), 7.62-7.53$ $(\mathrm{m}, 2 \mathrm{H}), 7.09(\mathrm{dd}, J=15.5 \mathrm{~Hz}, 6.5 \mathrm{~Hz}, 1 \mathrm{H}), 6.99(\mathrm{dd}, J=15.5 \mathrm{~Hz}, 1.0 \mathrm{~Hz}, 1 \mathrm{H}), 2.35-2.26(\mathrm{~m}, 1 \mathrm{H}), 1.90-1.71(\mathrm{~m}, 5 \mathrm{H}), 1.41-1.19(\mathrm{~m}, 5 \mathrm{H})$. ${ }^{13}$ C NMR (101 MHz; $\left.\mathrm{CDCl}_{3}\right): \delta$ 191.2, 155.0, 135.6, 135.5, 132.6, 130.0, 129.6, 128.5, 128.3, 127.9, 126.8, 124.7, 123.4, 41.2, 32.0, 26.11, 25.9 .

HRMS (ESI) : m/z calcd for $\mathrm{C}_{19} \mathrm{H}_{21} \mathrm{O}: 265.15924 ;[\mathrm{M}+\mathrm{H}]^{+}$found 265.1593 (0 ppm).

\section{(E)-5,5-dimethyl-1-phenylhex-2-en-1-one (1d)}

According the literature procedure ${ }^{17}$ and starting from 3,3-dimethylbutyraldehyde (4 mmol), the desired enone 1d was obtained in $56 \%$ yield $(457 \mathrm{mg})$.

${ }^{1}$ H NMR $\left(400 \mathrm{MHz} ; \mathrm{CDCl}_{3}\right): \delta$ 7.95-7.92 (m, 2H), 7.57-7.53 (m, 1H), 7.49-7.44 (m, 2H), 7.10 (dt, $\left.J=15.4 \mathrm{~Hz}, 7.7 \mathrm{~Hz}, 1 \mathrm{H}\right), 6.86(\mathrm{dt}, J=$ $15.3 \mathrm{~Hz}, 1.3 \mathrm{~Hz}, 1 \mathrm{H}), 2.21(\mathrm{dd}, J=7.8 \mathrm{~Hz}, 1.3 \mathrm{~Hz}, 2 \mathrm{H}), 0.97(\mathrm{~s}, 9 \mathrm{H})$.

${ }^{13} \mathrm{C}$ NMR (101 MHz; $\left.\mathrm{CDCl}_{3}\right): \delta 190.6,147.4,138.0,132.5,128.48,128.46,127.9,47.3,31.6,29.5$.

HRMS (ESI) : $\mathrm{m} / \mathrm{z}$ calcd for $\mathrm{C}_{14} \mathrm{H}_{18} \mathrm{ONa}$ : 225.12554; [M+Na $]^{+}$found $225.1253(1 \mathrm{ppm})$. 


\section{1,4-asymmetric conjugate addition on $\alpha$-aryl enones: Typical Procedure}

A flame dried Schlenk flask, under an argon atmosphere, was charged with $(R)$-BINAP ligand (12.5 mg, $0.02 \mathrm{mmol}, 5 \mathrm{~mol} \%)$, CuTc (3.8 $\mathrm{mg}, 0.02 \mathrm{mmol}, 5 \mathrm{~mol} \%)$ and dry THF $(0.5 \mathrm{~mL})$. The resulting mixture was stirred for $10 \mathrm{~min}$ at room temperature and to this solution was added dropwise a solution of dialkylzinc reagent (3 equiv.) The reaction mixture was stirred for $10 \mathrm{~min}$ at room temperature and a solution of substrate $1(0.4 \mathrm{mmol}, 1$ equiv. $)$ in $0.5 \mathrm{~mL}$ of dry THF was added. The reaction mixture was stirred at room temperature for $14 \mathrm{~h}$ for the product $2 \mathrm{a}, 16 \mathrm{~h}$ for $2 \mathrm{c}$ and $\mathbf{2 e}, 36 \mathrm{~h}$ for $\mathbf{2 d}$ and $24 \mathrm{~h}$ for $\mathbf{2 g}$ and $\mathbf{2 i}$. The reaction was quenched by the addition of ethanol $(4 \mathrm{~mL})$. The mixture was stirred for $15 \mathrm{~min}$ and filtered through a short column of silica gel with EtOAc. The solvents were removed under reduced pressure. The crude mixtures were purified by flash chromatography on silica gel (pentane/Et $2 \mathrm{O}: 98 / 2$ ) to afford the corresponding products as colorless oils. Ee was obtained by GC or HPLC analysis of the purified product.

\section{3-cyclohexyl-1-phenylpentan-1-one (2a)}

Using the typical procedure with $(R)$-BINAP, $(S)$-2a was obtained in 92\% yield $(90 \mathrm{mg})$ and 97\% ee (HPLC: Chiralcel IA column, $n$ -

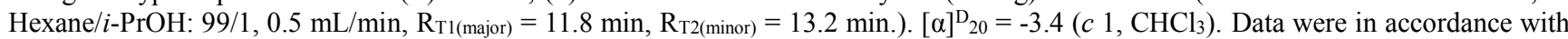
the literature. ${ }^{10 b, 20}$

\section{3-cyclohexyl-1-(naphthalen-2-yl)pentan-1-one (2c)}

Using the typical procedure with $(R)$-BINAP, 2c was obtained in $89 \%$ yield $(105 \mathrm{mg}$ ) and 94\% ee (HPLC: Chiralcel OJ-H column, $n$ Hexane, $0.5 \mathrm{~mL} / \mathrm{min} ., \mathrm{R}_{\mathrm{T} 1 \text { (major) }}=38.2 \mathrm{~min} ., \mathrm{R}_{\mathrm{T} 2 \text { (minor) }}=44.3 \mathrm{~min}$.). $[\alpha]^{\mathrm{D}_{20}}=-15.6\left(c 1, \mathrm{CHCl}_{3}\right)$.

${ }^{1}$ H NMR $\left(400 \mathrm{MHz} ; \mathrm{CDCl}_{3}\right): \delta 8.47(\mathrm{~s}, 1 \mathrm{H}), 8.04(\mathrm{dd}, J=8.6 \mathrm{~Hz}, 1.8 \mathrm{~Hz}, 1 \mathrm{H}), 7.98(\mathrm{~d}, J=7.9 \mathrm{~Hz}, 1 \mathrm{H}), 7.90(\mathrm{t}, J=7.8 \mathrm{~Hz}, 2 \mathrm{H}), 7.63-7.54$ $(\mathrm{m}, 2 \mathrm{H}), 3.11(\mathrm{dd}, J=16.1 \mathrm{~Hz}, 5.6 \mathrm{~Hz}, 1 \mathrm{H}), 2.91(\mathrm{dd}, J=16.1 \mathrm{~Hz}, 7.5 \mathrm{~Hz}, 1 \mathrm{H}), 2.07-2.00(\mathrm{~m}, 1 \mathrm{H}), 1.78-1.53(\mathrm{~m}, 5 \mathrm{H}), 1.49-1.44(\mathrm{~m}, 2 \mathrm{H})$, $1.38-1.05(\mathrm{~m}, 6 \mathrm{H}), 0.90(\mathrm{t}, J=7.4 \mathrm{~Hz}, 3 \mathrm{H})$

${ }^{13}$ C NMR (101 MHz; $\left.\mathrm{CDCl}_{3}\right): \delta 201.1,135.6,135.0,132.7,129.69,129.67,128.5,128.4,127.9,126.8,124.2,41.4,40.5,40.4,30.5,29.5$, $27.0,26.95,26.92,24.2,12.1$.

HRMS (ESI) : m/z calcd for $\mathrm{C}_{21} \mathrm{H}_{26} \mathrm{ONa}: 317.18814$; [M+Na] $]^{+}$found 317.1877 (1 ppm).

\section{3-cyclohexyl-4-methyl-1-phenylpentan-1-one (2d)}

Using the typical procedure with $(R)$-BINAP, 2 d was obtained in $54 \%$ yield $(56 \mathrm{mg})$ and $12 \%$ ee (HPLC: Chiralcel IA column, $n$-Hexane/iPrOH: 99/1, $\left.0.5 \mathrm{~mL} / \mathrm{min} ., \mathrm{R}_{\mathrm{T} 1 \text { (major) }}=11.6 \mathrm{~min}, \mathrm{R}_{\mathrm{T} 2 \text { (minor })}=13.4 \mathrm{~min}.\right) .[\alpha]^{\mathrm{D}_{20}}=-0.7\left(c 1, \mathrm{CHCl}_{3}\right)$.

${ }^{1}$ H NMR $\left(400 \mathrm{MHz} ; \mathrm{CDCl}_{3}\right): \delta 8.00-7.97(\mathrm{~m}, 2 \mathrm{H}), 7.57-7.53(\mathrm{~m}, 1 \mathrm{H}), 7.49-7.44(\mathrm{~m}, 2 \mathrm{H}), 2.88(\mathrm{dd}, J=17.7 \mathrm{~Hz}, 5.9 \mathrm{~Hz}, 1 \mathrm{H}), 2.80(\mathrm{dd}, J$ $=17.7 \mathrm{~Hz}, 5.1 \mathrm{~Hz}, 1 \mathrm{H}), 2.04$ (quint, $J=5.6 \mathrm{~Hz}, 1 \mathrm{H}), 1.92-1.80(\mathrm{~m}, 1 \mathrm{H}), 1.75-1.66(\mathrm{~m}, 3 \mathrm{H}), 1.65-1.52(\mathrm{~m}, 2 \mathrm{H}), 1.43-1.34(\mathrm{~m}, 1 \mathrm{H}), 1.27-$ $0.93(\mathrm{~m}, 5 \mathrm{H}), 0.90(\mathrm{~d}, J=6.8 \mathrm{~Hz}, 3 \mathrm{H}), 0.81(\mathrm{~d}, J=6.8 \mathrm{~Hz}, 3 \mathrm{H})$.

${ }^{13} \mathrm{C}$ NMR (101 MHz; $\left.\mathrm{CDCl}_{3}\right): \delta$ 200.7, 137.6, 132.8, 128.6, 128.1, 44.1, 40.3, 37.7, 31.8, 30.1, 28.8, 26.94, 26.91, 26.8, 21.6, 18.9.

HRMS (ESI) : $\mathrm{m} / \mathrm{z}$ calcd for $\mathrm{C}_{18} \mathrm{H}_{26} \mathrm{ONa}: 281.18814$; $[\mathrm{M}+\mathrm{Na}]^{+}$found 281.1883 (1 ppm).

\section{3-ethyl-5,5-dimethyl-1-phenylhexan-1-one (2e)}

Using the typical procedure with $(R)$-BINAP, 2e was obtained in $96 \%$ yield $(84 \mathrm{mg})$ and $91 \%$ ee (HPLC: Chiralcel OJ-H column, $n$-Hexane, $0.2 \mathrm{~mL} / \mathrm{min}, \mathrm{R}_{\mathrm{T} 1 \text { (major) }}=38.4 \mathrm{~min} ., \mathrm{R}_{\mathrm{T} 2 \text { (minor) }}=43.9 \mathrm{~min}$. $)$. $[\alpha]^{\mathrm{D}_{20}}=-16.3\left(\mathrm{c} 1, \mathrm{CHCl}_{3}\right)$.

${ }^{1}$ H NMR $\left(400 \mathrm{MHz} ; \mathrm{CDCl}_{3}\right): \delta$ 7.97-7.94 (m, 2H), 7.57-7.52 (m, 1H), 7.48-7.43 (m, 2H), $2.99(\mathrm{dd}, J=16.3 \mathrm{~Hz}, 7.5 \mathrm{~Hz}, 1 \mathrm{H}), 2.83(\mathrm{dd}, J$ $=16.3 \mathrm{~Hz}, 5.6 \mathrm{~Hz}, 1 \mathrm{H}), 2.13-2.05(\mathrm{~m}, 1 \mathrm{H}), 1.40-1.33(\mathrm{~m}, 2 \mathrm{H}), 1.29(\mathrm{dd}, J=13.6 \mathrm{~Hz}, 5.2 \mathrm{~Hz}, 1 \mathrm{H}), 1.19(\mathrm{dd}, J=14.2 \mathrm{~Hz}, 5.3 \mathrm{~Hz}, 1 \mathrm{H}), 0.91-$ $0.88(\mathrm{~m}, 12 \mathrm{H})$.

${ }^{13}$ C NMR (101 MHz; $\left.\mathrm{CDCl}_{3}\right): \delta 200.6,137.7,132.9,128.7,128.2,47.8,45.4,32.3,31.2,30.1,29.3,11.3$.

HRMS (ESI) : m/z calcd for $\mathrm{C}_{16} \mathrm{H}_{24} \mathrm{ONa}: 255.17249$; [M+Na $]^{+}$found : 255.1726 (0 ppm).

\section{3,5,5-trimethyl-1-phenylhexan-1-one (2g)}

Using the typical procedure with $(R)$-BINAP, $2 \mathrm{~g}$ was obtained in $44 \%$ yield $(38 \mathrm{mg})$ and $93 \%$ ee (GC: G-TA column, helium $(40 \mathrm{~cm} / \mathrm{sec})$, $100{ }^{\circ} \mathrm{C}-150 \mathrm{~min} .-5{ }^{\circ} \mathrm{C} / \mathrm{min} .-160{ }^{\circ} \mathrm{C}-10 \mathrm{~min}$., $\mathrm{Rt}_{1 \text { (minor) }}=135.3 \mathrm{~min}$., $\mathrm{Rt}_{2 \text { (major) }}=140.9 \mathrm{~min}$.). $[\alpha]^{\mathrm{D}_{20}}=-13.2\left(\mathrm{c} 1, \mathrm{CHCl}_{3}\right)$.

${ }^{1} \mathbf{H}$ NMR $\left(400 \mathrm{MHz} ; \mathrm{CDCl}_{3}\right): \delta 7.96-7.93(\mathrm{~m}, 2 \mathrm{H}), 7.57-7.53(\mathrm{~m}, 1 \mathrm{H}), 7.48-7.44(\mathrm{~m}, 2 \mathrm{H}), 2.92(\mathrm{dd}, J=15.9,5.7 \mathrm{~Hz}, 1 \mathrm{H}), 2.82(\mathrm{dd}, J=$ $15.9,8.0 \mathrm{~Hz}, 1 \mathrm{H}), 2.32-2.21(\mathrm{~m}, 1 \mathrm{H}), 1.32(\mathrm{dd}, J=14.0,4.0 \mathrm{~Hz}, 1 \mathrm{H}), 1.18(\mathrm{dd}, J=14.0,6.5 \mathrm{~Hz}, 1 \mathrm{H}), 1.00(\mathrm{~d}, J=6.6 \mathrm{~Hz}, 3 \mathrm{H}), 0.91(\mathrm{~s}$, 9H).

${ }^{13} \mathbf{C}$ NMR $\left(101 \mathrm{MHz} ; \mathrm{CDCl}_{3}\right): \delta 200.4,137.6,132.9,128.7,128.2,51.2,48.3,31.3,30.2,26.5,23.1$.

HRMS (ESI) : m/z calcd for $\mathrm{C}_{15} \mathrm{H}_{22} \mathrm{ONa}$ : 241.15684; [M+Na $]^{+}$found : 241.1567 (1 ppm).

\section{3-ethyl-4,4-dimethyl-1-phenylpentan-1-one (2i)}

Using the typical procedure with $(R)$-BINAP, $2 \mathbf{i}$ was obtained in $22 \%$ yield (determined by ${ }^{1} \mathrm{H}$ NMR using mesitylene as an internal standard) and $0 \%$ ee (HPLC: Chiralcel OJ column, $n$-Hexane, $0.2 \mathrm{~mL} / \mathrm{min} ., \mathrm{R}_{\mathrm{T} 1}=28.9 \mathrm{~min} ., \mathrm{R}_{\mathrm{T} 2}=38.1 \mathrm{~min}$.). Data were in accordance with the literature. ${ }^{12}$

\section{1,4-asymmetric conjugate addition on $\alpha$-aryl dienone (1g): Typical Procedure}

A flame dried Schlenk flask, under an argon atmosphere, was charged with diphosphine ligand (0.025 mmol, $5 \mathrm{~mol} \%)$, CuTc (4.8 mg, $0.025 \mathrm{mmol}, 5 \mathrm{~mol} \%)$ and dry THF $(0.5 \mathrm{~mL})$. The resulting mixture was stirred for $10 \mathrm{~min}$ at room temperature and to this solution was added dropwise a $1 \mathrm{M}$ solution of diethylzinc in hexanes $(1.5 \mathrm{~mL}, 1.5 \mathrm{mmol}, 3$ equiv.). The reaction mixture was stirred for $10 \mathrm{~min}$ at room temperature and a solution of substrate $1 \mathrm{~g}(117 \mathrm{mg}, 0.5 \mathrm{mmol}, 1$ equiv.) in $0.5 \mathrm{~mL}$ of dry THF was added. The reaction mixture was stirred at $0{ }^{\circ} \mathrm{C}$ until the completion. The reaction was quenched by the addition of ethanol $(4 \mathrm{~mL})$. The mixture was stirred for $15 \mathrm{~min}$ and filtered through a short column of silica gel with EtOAc. The solvents were removed under reduced pressure. The crude mixtures were purified by flash chromatography on silica gel (pentane/Et $2 \mathrm{O}: \mathbf{9 8 / 2}$ ) to afford the corresponding mixture of adducts $\mathbf{2} \mathbf{j} / \mathbf{2} \mathbf{j}$ ' as colorless oils. Data were in accordance with literature. ${ }^{7}$ Ee was obtained by chiral HPLC analysis of the purified product (Chiralcel OJ-H column, $n$-Hexane $/ i$-PrOH: 99/1, $1 \mathrm{~mL} / \mathrm{min}, \mathrm{R}_{\mathrm{T} 1(1,4 \text { adduct, minor) }}=18.1 \mathrm{~min}, \mathrm{R}_{\mathrm{T} 2(1,4 \text { adduct, major })}=20.0 \mathrm{~min}$.). 
With $(R)$-BINAP: After 3 h of reaction, a $96 / 4$ mixture of adducts $\mathbf{2 j} / \mathbf{2} \mathbf{j}$ ' was isolated in $82 \%$ yield (109 $\mathrm{mg}$ ) and $92 \%$ ee. With (S)-SYNPHOS: After 5 h of reaction, a $97 / 3$ mixture of adducts $\mathbf{2 j} / \mathbf{2 j}$ ' was isolated in $70 \%$ yield $(92 \mathrm{mg})$ and $-54 \%$ ee. With $(R)$-DIFLUORPHOS: After 6 h of reaction, a $95 / 5$ mixture of adducts $\mathbf{2} \mathbf{j} / \mathbf{2} \mathbf{j}$ ' was isolated in $66 \%$ yield $(87 \mathbf{m g})$ and $80 \%$ ee.

\section{1,6-asymmetric conjugate addition on dienone (1h): Typical Procedure}

A flame dried Schlenk flask, under an argon atmosphere, was charged with diphosphine ligand $(0.025 \mathrm{mmol}, 5 \mathrm{~mol} \%), \mathrm{CuTc}(4.8 \mathrm{mg}$, $0.025 \mathrm{mmol}, 5 \mathrm{~mol} \%)$ and dry THF $(1 \mathrm{~mL})$. The resulting mixture was stirred for $10 \mathrm{~min}$. A $1 \mathrm{M}$ solution of diethylzinc in hexanes $(1.5 \mathrm{~mL}$, $1.5 \mathrm{mmol}, 3$ equiv.) was added and the reaction mixture was stirred for $10 \mathrm{~min}$. Finally, a solution of substrate $\mathbf{1 h}(90 \mathrm{mg}, 0.5 \mathrm{mmol}, 1$ equiv.) in $0.5 \mathrm{~mL}$ of THF was added. The reaction mixture was stirred at room temperature until the completion. The reaction was quenched by the addition of solid $\mathrm{NH}_{4} \mathrm{Cl}(500 \mathrm{mg})$. The solution was stirred for $1 \mathrm{~h}$ and then filtered on a small pad of silica, washed with EtOAc, and concentrated under vacuo. The residue was dissolved in $4 \mathrm{~mL}$ of dry $\mathrm{CH}_{2} \mathrm{Cl}_{2}$ and $\mathrm{DBU}(100 \mathrm{~mL}, 0.7 \mathrm{mmol}, 1.4$ equiv) was added to the solution. The reaction was stirred for $5 \mathrm{~h}$ and then filtered on a small pad of silica, washed with EtOAc, and concentrated under vacuo. The crude product was purified by flash chromatography on silica gel (pentane/Et $2 \mathrm{O}: 85 / 15$ ) to afford 2k. Data were in accordance with literature. ${ }^{13 \mathrm{~b}} \mathrm{Ee}$ was obtained by GC analysis of the purified product (Beta-dex column, helium $(40 \mathrm{~cm} / \mathrm{sec}), 100{ }^{\circ} \mathrm{C}-400 \mathrm{~min}-5^{\circ} \mathrm{C} / \mathrm{min}-170$ ${ }^{\circ} \mathrm{C}-10$ min, $\mathrm{Rt}_{1 \text { (minor) }}=380.5$ min, $\mathrm{Rt}_{2 \text { (major) }}=385.4$ min.)

With $(R)$-BINAP: After $5 \mathrm{~h}$ of reaction, $2 \mathrm{k}$ was isolated in $60 \%$ yield $(63 \mathrm{mg})$ and $82 \%$ ee.

With $(S)$-SYNPHOS: After $14 \mathrm{~h}$ of reaction, $2 \mathbf{k}$ was isolated in $54 \%$ yield $(56 \mathrm{mg})$ and $-82 \%$ ee.

With $(R)$-DIFLUORPHOS: After $14 \mathrm{~h}$ of reaction, $\mathbf{2 k}$ was isolated in $14 \%$ yield (determined by ${ }^{1} \mathrm{H}$ NMR using mesitylene as an internal standard) and $74 \%$ ee.

\section{Acknowledgement}

This work was supported by the Agence Nationale de la Recherche (SCATE, ${ }^{\circ}$ ANR-12-B507-0009-01; grant to MSTM). MM and OB also thank the CNRS.

\section{Supporting Information}

Supporting information for this article is available online at http://dx.doi.org/.

\section{References}

(1) For metal-catalysed asymmetric nucleophile addition to electron-deficient alkenes, see: (a) Mauduit, M.; Baslé, O.; Clavier, H.; Crévisy, C.; Denicourt-Nowicki, A. In Comprehensive Organic Synthesis II, vol. 4 (Knochel, P., Molander G. A.) Eds, Elsevier, 2014, pp 186; For an excellent comprehensive review, see also: (b) Hawner, C.; Alexakis, A. Chem. Commun. 2010, 46, 7295.

(2) For Cu-catalysed ACA, see: (a) Copper-Catalyzed Asymmetric Synthesis; Alexakis, A.; Krause, N.; Woodward, S., Eds.; Wiley-VCH: Weinheim, Germany 2014. (b) Jerphagnon, T.; Pizzuti, M. G.; Minnaard, A. J.; Feringa, B. L. Chem. Soc. Rev. 2009, 38, 1039. (c) Alexakis, A.; Bäckvall, J.; Krause, N.; Pàmies, O.; Diéguez, M. Chem. Rev. 2008, 108, 2796.

(3) den Hartog, T.; Rudolph, A.; Macia, B.; Minnaard, A. J.; Feringa, B. L., J. Am. Chem. Soc., 2010, 132, 14349.

(4) (a) Wang, S.-Y.; Ji, S.-J.; Loh, T.-P. J. Am. Chem. Soc. 2007, 129, 276-277. (b) Wang, S.-Y.; Lum, T.-K.; Ji, S.-J.; Loh, T.-P. Adv. Synth. Catal. 2008, 350, 673. (c) Wang, S.-Y.; Song, P.; Loh, T.-P. Adv. Synth. Catal. 2008, 350, 3185. (d) Wang, S.-Y.; Loh, T.-P. Chem. Commun. 2010, 46, 8694; see also ref.3

(5) (a) Maciá Ruiz, B.; Geurts, K.; Fernández-Ibáñez, M. A.; ter Horst, B.; Minnaard, A. J.; Feringa, B. L. Org. Lett. 2007, 9, 5123. (b) Lee, J. C. H.; Hall, D. G. J. Am. Chem. Soc. 2010, 132, 5544.

(6) Gremaud, L.; Alexakis, A. Angew. Chem. Int. Ed. 2012, 51, 794.

(7) Magrez-Chiquet, M; Morin, M. S. T.; Wencel-Delord, J.; Drissy Amraoui , S. ; Baslé, O. ; Alexakis, A.; Crévisy, C.; Mauduit, M. Chem. Eur. J, 2013, 19, 13663.

(8) (a) Duprat de Paule, S.; Champion, N.; Ratovelomanana-Vidal, V.; Genet, J.-P.; Dellis, P. FR2830254, EP1436304, 2001, WO Patent 03029259, 2003. (b) Duprat de Paule, S.; Jeulin, S.; Ratovelomanana-Vidal, V.; Genêt, J.-P.; Champion, N.; Dellis, P. Eur. J. Org. Chem. 2003, 1931. (c) Duprat de Paule, S.; Jeulin, S.; Ratovelomanana-Vidal, V.; Genet, J. P.; Champion, N.; Deschaux, G.; Dellis, P. Org. Process Res. Dev. 2003, 7, 399.

(9) (a) Jeulin, S.; Duprat de Paule, S.; Ratovelomanana-Vidal, V.; Genêt, J.-P.; Champion, N.; Dellis, P. Angew. Chem. Int. Ed. 2004, 43, 320. (b) Jeulin, S.; Duprat de Paule, S.; Ratovelomanana-Vidal, V.; Genet, J.-P.; Champion, N.; Dellis, P. Proc. Natl. Acad. Sci. U.S.A. 2004, 101, 5799. (c) Genêt, J.-P.; Ayad, T.; Ratovelomanana-Vidal, V. Chem. Rev. 2014, 114, 2824.

(10) To the best of our knowledge, only two reports disclose the 1,4-adduct 2 a with a maximum of $77 \%$ yield and $96 \%$ ee, with $\mathrm{Cu}-\mathrm{ACA}$ processes involving phosphino-based BINOL or SPINOL ligands: (a) Endo, K.; Ogawa, M.; Shibata, T. Angew. Chem. Int. Ed. 2010, 49, 2410. (b) Endo, K.; Hamada, D.; Yakeishi, S.; Ogawa, M.; Shibata, T. Org. Lett. 2012, 14, 2342.

(11) To the best of our knowledge, only one report mentioned this challenging ACA with lower yield of 5\% but higher ee up to 74\%, see: Takahashi, Y.; Yamamoto, Y.; Katagari, K.; Danjo, H.; Yamaguchi, K.; Imamoto, T. J. Org. Chem. 2005, 70, 9009.

(12) For a review dealing with ACA on extended Michael acceptors, see : Csaky, A. G.; de la Herran, G.; Murcia, M. C. Chem. Soc. Rev. 2010, 39, 4080 . 
(13) For examples of Cu-catalyzed ACA on conjugated dienones, see: (a) Fillion, E.; Wilsily, A.; Liao, E.-T. Tetrahedron: Asymmetry 2006, 17, 2957. (b) Henon, H.; Mauduit, M.; Alexakis, A. Angew. Chem. Int. Ed. 2008, 47, 9122. (c) Wencel-Delord, J.; Alexakis, A.; Crévisy, C.; Mauduit, M. Org. Lett. 2010, 12, 4335. (d) Tissot, M.; Poggiali, D.; Henon, H.; Müller, D.; Guénée, L.; Mauduit, M.; Alexakis, A. Chem Eur. J. 2012, 18, 8731. (e) Magrez, M. Wencel-Delord, J.; Alexakis, A.; Crévisy, C.; Mauduit, M. Org. lett. 2012, 14, 3576. (f) Ma, Z.; Xie, F.; Yu, Han.; Zhang, Y.; Wu, X.; Zhang, W., Chem. Commun. 2013, 49, 5292.

(14) Coates, R. M.; Sowerby, R. L. J. Am. Chem. Soc., 1972, 94, 5386.

(15) For instance, it was observed that the $\mathrm{Cu}$ /phosphoramidite catalysed addition of $\mathrm{Et}_{2} \mathrm{Zn}$ or $\mathrm{Et}_{3} \mathrm{Al}$ to a cyclic dienone structurally close to $\mathbf{1 h}$ gave the 1,6-adduct, whereas the $\mathrm{Cu} / \mathrm{NHC}$ catalysed addition of a Grignard reagent led to the 1,4-adduct. See reference $13 \mathrm{~b}$.

(16) For a specific review on BINAP, see: (a) Noyori, R.; Takaya, H. Acc. Chem. Res. 1990, 23, 345. For industrial enantioselective metal-catalytic processes using BINAP, see: (b) Akutagawa, S. Appl. Catal. A: General 1995, 128, 171.

(17) Liu, D.-N.; Tian, S.-K. Chem. Eur. J. 2009, 15, 4538

(18) Pinto, Diana C. G. A.; Silva, Artur M. S.; Lévai, A.; Cavaleiro, José A. S.; Patonay, T.; Elguero, J. Eur. J. Org. Chem. 2000, 2000, 2593

(19) Rana, N. K.; Selvakumar, S.; Singh, V. K. J. Org. Chem. 2010, 75, 2089

(20) Shintani, R.; Fu, G. C. Org. Lett. 2002, 4, 3699

\section{Graphical Abstract}

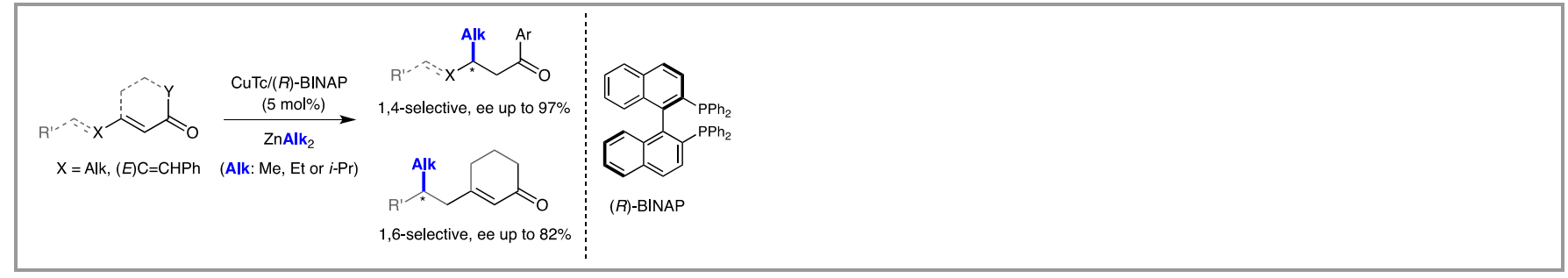

